\title{
Vote Transfers, Thwarted Voters and Newcomers in the 2009 Presidential Runoff in Romania
}

\author{
Andrei Gheorghiță ${ }^{1}$ * \\ ${ }^{1}$ Lucian Blaga University of Sibiu, Department of Sociology and Social Work, 2-4 Lucian Blaga, 550169 Sibiu, Romania
}

KEYWORDS

Romania

2009 presidential election

runoff

Thwarted voters

Vote transfers

Romanian Election

Studies
ABSTRACT

This article investigates the role of thwarted voters and newcomers in setting the result of the December $6^{\text {th }}, 2009$ presidential runoff in Romania. For this purpose it employs panel survey data from the Romanian Election Studies, collected across three waves: pre-election, between the two rounds, post-election. Initially, it draws a picture of the main evolutions in turnout and vote between the first and the second round, with a special emphasis on vote transfers and risks associated to turnout and pro-winner overreporting. Then it analyzes the thwarted voters and their rationalities of making secondorder electoral choices in the presidential runoff. The influence of campaign developments and long-term party/candidate preferences is assessed. Finally, the article investigates the profile of newcomers (people only voting in the runoff) and the mechanisms of political mobilisation in their case. A special attention is given to how newcomers make the electoral choice in the presidential runoff and to the influence of the campaign developments on that choice.

\section{General context}

Traian Băsescu winning the runoff of the 2009 presidential elections in Romania was quite a surprise for the electoral analysts. In fact, they might have found the result even more spectacular than ordinary voters did, as they were more aware of the campaign developments. Why was it a surprise? First, because opinion polls during the last month before the election unanimously stated Mircea Geoană would win by a margin of 6 to 8

\footnotetext{
* Contact address: andrei.gheorghita@ulbsibiu.ro (A. Gheorghiță)
} 
percent over Traian Băsescu. Second, after the first round of election, the social-democrat candidate received explicit or implicit support of all major candidates leaving the competition after the first round. Third, although Traian Băsescu won the final television debate, it wasn't a clear-cut victory, that might compensate for the distance in opinion polls. Last, few analysts might have imagined the votes of Diaspora to be decisive for the result of the presidential competition. Exit polls (and later the Central Electoral Bureau) confirmed Mircea Geoană winning the runoff across polling stations within Romanian borders. However, Traian Băsescu has been the overall winner of the December 6 presidential runoff.

In order to set Traian Băsescu's unexpected victory in a proper framework of understanding, at least two observations are needed. First, his overall victory across polling stations abroad was large enough to compensate for the fragile advantage of Mircea Geoană across domestic polling stations. Second, the overall distance between the two candidates in terms of domestic vote was of only $0.14 \%$ in favour of Geoană, significantly smaller than what pollsters predicted. Any explanation of the official result of the presidential runoff is definitely to be searched at the intersection of these two observations.

Let us consider the first one in relation to the official data from the Central Electoral Bureau (BEC). A higher electoral mobilization of Diaspora in the runoff compared to the first round is obvious, as turnout increases by over $55 \%$. The share of Diaspora votes in favour of Traian Băsescu goes from $56.05 \%$ in the first round to $78.86 \%$ in the second round (a gain of 62,977 voters and $119 \%$ ), while Mircea Geoană goes up from $12.41 \%$ to a modest $21.14 \%$ (a gain of 19,328 voters and 165\%). In the absence of survey data for the Diaspora, it is quite impossible to assess how stable were the electorates of the two candidates between the two rounds or to estimate the vote distribution of thwarted voters and newcomers in the runoff. Although this research direction is a dead end due to the lack of data, the remarkable mobilization of Diaspora voters in the second round, apparently with positive effects for the success of Traian Băsescu, should be emphasized at this level.

The second observation is definitely more promising in terms of empirical investigation. If a 'theoretical' distribution of votes is to be 
considered, Mircea Geoană was expected to easily win the runoff (by more than $60 \%$ ) over domestic polling stations. The actual distribution of votes confirmed his victory, however by a feeble (and insufficient) margin. Such a gap between the theoretical vote and the actual one might originate in several possible campaign developments: (a) a mobilization scenario, according to which a considerable number of newcomers voted in the second round, overwhelmingly in favour of Traian Băsescu; (b) a demobilization scenario, according to which a large share of thwarted voters did not vote in the second round, thus making runoff-support alliances futile; (c) a campaign context scenario, according to which several campaign developments between the two rounds might have generated switches in the electoral choice or defections from the 'recommended' vote. It is a rather common finding in electoral research that thwarted voters do not 'automatically' redirect their vote towards the runoff contender indicated by their first round preferred candidate. It is not unusual for such a voter to experience a dissonance between the support recommendation of the first round preferred candidate and his/her values, opinions or sympathies; such a dissonance might convert into vote abstention or even a contrary vote. Such deviations from the 'theoretical' vote due to dissonances are very likely in the case of Mircea Geoană, given the extremely heterogeneous runoff support in terms of ideologies, traditional political conflicts, etc. Fortunately these analytical directions can be subject to in-depth investigation based on panel data from the Romanian Election Studies (RES) surveys. They are the central focus of this article. There are obvious limitations deriving from the nature of survey data employed (vote for the winner overreporting, analyses on small subsamples, etc.) that are discussed when necessary.

\section{Evolutions in turnout and vote between the two rounds}

There are many dangers in analysing such developments using survey data. Findings may be subject to serious bias due to at least two categories of overreporting effects. First, turnout overreporting occurs. This means that postelection survey data usually show a turnout rate that is significantly higher than the official one, introducing obvious biases: analyses are performed on a subsample of presumed voters; however some of them are fake voters 
whose answers are treated as if they belonged to genuine voters. Turnout overreporting is usually explained in the literature as a combination of social desirability effects and limitations of human memory. Unfortunately, in the case of RES survey, these effects are overlapped by a panel study effect and a contextual one. In the first case, respondents to a panel study tend to become better informed and more participative, since they are aware of being questioned over several waves. In the second case, Romanian statistics appear to underestimate official turnout (see Comșa 2012; Rotariu 2012). All these three categories of effects (turnout overreporting, raise in electoral awareness due to panel effects, and official turnout underestimation) contribute to an increase in the estimated gap between official and selfreported turnout ${ }^{1}$.

Second, an overreporting in vote for the winner might occur, in relation or not with turnout overreporting. Post-election survey data usually indicate a larger share of pro-winner votes compared to official results. This might be the consequence of at least two alternative scenarios: either the pretended voters (as discussed above) report voting for the winner more frequently than the rest of the electorate (double overreporting), or there are genuine voters who report a false pro-winner vote 2 (winner overreporting). Usually, the literature does not differentiate between the two scenarios, as they are assumed to have a common origin. When the distance in time between the act of voting and the survey is reasonably short (as it is the case for the RES study), therefore the risk of memory failures is low, explanations of prowinner overreporting are linked to various stances of the social desirability phenomenon. It might be a case of bandwagon effect, as depicted by Lazarsfeld, Berelson, and Gaudet (1968 [1944]), that states the existence of a category of voters that wish to be associated to the winner and hence report a false vote in favour of him/her (or do not report their genuine vote for the loser). Or it might be due to some sort of fear of social isolation that makes people self-censor minoritarian opinions and positions (in this case vote for the defeated candidate), conceptualised through Noelle-Neumann's spiral of

1 In fact, there are two components of this gap: a genuine one, mainly due to social desirability effects, and a virtual one, due to panel effect and context effect. The second component generates only a virtual error in the analysis, as we are dealing with respondents who genuinely voted.

${ }^{2}$ Or, reversely, do not report a vote in favour of the defeated candidate. 
silence (1984). No matter the reasons that lie behind pro-winner vote overreporting, there is no doubt it can introduce serious bias in surveybased analyses of electoral choice. However, the extreme polarization of the electoral context and the relative balance between the numbers of supporters of the two sides are likely to have contributed to rather small and isolated pro-winner overreporting effects.

In the light of these threats for the investigation, an estimation of overreporting effects is definitely a must before proceeding to further analyses on RES panel data. The findings are presented in tables 1 and 2 . First, turnout overreporting is close to $28 \%$ for both rounds of the election, which is relatively high ${ }^{3}$. Second, data do not show an overreporting in vote for the winner ${ }^{4}$ in any of the two rounds. A reverse tendency can be observed immediately after the moment of elections (wave 2 after first round, wave 3 after runoff).

Furthermore, reported vote choices deviate little from the official results, especially when the runoff is to be considered. Another aspect that draws attention is that between waves 2 and 3 (both post factum) Mircea Geoană and Traian Băsescu switch places in the ranking of reported vote for the first round: while vote for the social-democrat candidate remains constant, the acting president grows by $1.7 \%$. This development might be related to variations in attrition rate between the two waves or it might reflect a 'pro-winner' effect after the runoff.

Table 1. Self-reported turnout compared to the official turnout

\begin{tabular}{|c|c|c|c|c|}
\hline \multicolumn{3}{|c|}{ First round } & \multicolumn{2}{|c|}{ Runoff } \\
\hline $\begin{array}{l}\text { Self-reported } \\
\text { turnout } \\
\text { (RES, wave 2) }\end{array}$ & $\begin{array}{l}\text { Self-reported } \\
\text { turnout } \\
\text { (RES, wave 3) }\end{array}$ & Official turnout & $\begin{array}{c}\text { Self-reported } \\
\text { turnout } \\
\text { (RES, wave 3) }\end{array}$ & Official turnout \\
\hline $86.9 \%$ & $82.6 \%$ & $54.3 \%$ & $85.8 \%$ & $58.0 \%$ \\
\hline
\end{tabular}

3 Turnout overreporting is higher than the one suggested by studies dedicated to other elections in Romania. However, a significant share of reported turnout is expected to be genuine, due to an increase in awareness introduced by the panel study.

${ }^{4}$ Overall, both rounds have been won by Traian Băsescu, in spite of the unusual result of the runoff (the incumbent defeated across domestic polling stations, but winning after the counting of votes from abroad). Given the circumstances, vote for Traian Băsescu will be considered in measuring pro-winner vote overreporting for both rounds of the presidential elections. 
This picture on the magnitude of overreporting effects is far from being able to offer a solid answer to our initial question about how tolerable these effects are for further analyses. On the one side, the capacity of data to reproduce the real structure of vote for both rounds, with minimal errors, is encouraging. On the other side, the implications of the significant gap between the self-declared turnout and the official one are rather difficult to assess. In an optimistic scenario, the gap might be just a 'virtual' one, due to a panel survey effect combined with errors in official statistics. However, the pessimistic scenario cannot be ignored, particularly if it is combined with analyses on small-size subsamples. Such a risk should not be overlooked and asks for caution in interpreting the findings of this article.

Table 2. Self-reported vote compared to the official results

\begin{tabular}{|c|c|c|c|c|}
\hline \multirow[b]{2}{*}{ Candidate } & \multicolumn{4}{|c|}{ First round } \\
\hline & $\begin{array}{l}\text { Vote intention } \\
\text { (RES, wave } 1 \text { ) }\end{array}$ & $\begin{array}{r}\text { Self-reported } \\
\text { vote } \\
\text { (RES, wave 2) }\end{array}$ & $\begin{array}{r}\text { Self-reported } \\
\text { vote } \\
\text { (RES, wave 3) }\end{array}$ & $\begin{array}{l}\text { Official results } \\
\text { across domestic } \\
\text { polling stations }\end{array}$ \\
\hline Traian Băsescu & $31.8 \%$ & $33.7 \%$ & $35.4 \%$ & $32.22 \%$ \\
\hline Mircea Geoană & $35.6 \%$ & $34.5 \%$ & $34.4 \%$ & $31.34 \%$ \\
\hline \multirow[t]{3}{*}{ Crin Antonescu } & $18.4 \%$ & $21.4 \%$ & $18.9 \%$ & $20.05 \%$ \\
\hline & \multicolumn{4}{|c|}{ Runoff } \\
\hline & $\begin{array}{l}\text { Vote intention } \\
\text { (RES, wave 1) }\end{array}$ & $\begin{array}{l}\text { Vote intention } \\
\text { (RES, wave 2) }\end{array}$ & $\begin{array}{r}\text { Self-reported } \\
\text { vote } \\
\text { (RES, wave 3) }\end{array}$ & $\begin{array}{l}\text { Official results } \\
\text { across domestic } \\
\text { polling stations }\end{array}$ \\
\hline Traian Băsescu & $42.8 \%$ & $42.1 \%$ & $47.6 \%$ & $49.93 \%$ \\
\hline Mircea Geoană & $58.2 \%$ & $57.9 \%$ & $52.4 \%$ & $50.07 \%$ \\
\hline
\end{tabular}

What are the main evolutions in electoral turnout between the two rounds of the presidential election? First, there is a loss of almost $6 \%$ of voters from round one to round two. The loss is higher among the voters who are disappointed with the results of the first round and find it hard to make a second choice for the runoff. Consequently, $17 \%$ of Kelemen Hunor's voters, $15 \%$ of Corneliu Vadim Tudor's and 13\% of Sorin Oprescu's electorate do not return to the polls in the second round. In spite of Crin Antonescu's failure to enter the runoff, only $8 \%$ of his voters miss the second round, which is remarkably low. As expected, losses in the electorate of the two runoff contenders are small and rather similar (close to $4 \%$ ), with a minimal advantage in favour of Mircea Geoană. 
Second, more than $9 \%$ of the runoff voters are newcomers. They dominantly vote for Traian Băsescu, being significantly more favourable to the incumbent than the rest of the voters. Most of them are women $(64 \%)$ and come from urban areas (62\%). A further section of this article is dedicated to an extensive analysis of this category of voters.

Table 3. Runoff self-declared vote in relation to first round self-declared vote

\begin{tabular}{llrr}
\hline First round vote & & \multicolumn{2}{c}{ Runoff vote } \\
\cline { 3 - 4 } & & Traian Băsescu & Mircea Geoană \\
\hline Traian Băsescu & $\rightarrow$ & $96.7 \%$ & $3.3 \%$ \\
Mircea Geoană & $\rightarrow$ & $7.5 \%$ & $92.5 \%$ \\
Crin Antonescu & $\rightarrow$ & $22.3 \%$ & $77.7 \%$ \\
Corneliu Vadim Tudor & $\rightarrow$ & $42.4 \%$ & $57.6 \%$ \\
Kelemen Hunor & $\rightarrow$ & $47.8 \%$ & $52.2 \%$ \\
Sorin Oprescu & $\rightarrow$ & $37.0 \%$ & $63.0 \%$ \\
Newcomers & $\rightarrow$ & $59.2 \%$ & $40.8 \%$ \\
\hline
\end{tabular}

An analysis of vote transfers between the first and the second round is another direction of investigation particularly important for understanding the results of the 2009 presidential elections. As Table 3 shows, voter defections between finalists are not that frequent, but still cannot be neglected: Mircea Geoană loses more than $7 \%$ of first round supporters to Traian Băsescu, while the reverse phenomenon is less spread (3\%). If thwarted voters are not considered, the defections ratio suggests an advantage for the incumbent (similar voter losses, smaller defections, more newcomers).

However, vote transfers from candidates not entering the runoff are expected to have a stronger impact on the configuration of election results. What are the main findings on this level? The social-democrat leader is voted by more than three quarters of Crin Antonescu's electorate. This finding suggests a highly disciplined electorate that is obviously opposed to the candidate Traian Băsescu, despite ideological compatibilities. Losses in turnout are rather small for this category of voters and their support is extensively transferred (almost 78\%) towards Mircea Geoană ${ }^{5}$, the runoff contender indicated by Crin Antonescu.

5 Of course, the marginal effect of an alternative scenario cannot be ignored: some of Crin Antonescu's first round voters declare supporting Mircea Geoană in the runoff, but actually do not vote (generating turnout overreporting). Fake reporting might be explained in terms of guilt for their vote 'defection' with a possible impact for Traian Băsescu's narrow re-election. 
A similar tendency of vote transferring in favour of Mircea Geoană (perhaps not that clear-cut as ratio) can be identified among other categories of thwarted electorate: 58\% of Corneliu Vadim Tudor's supporters participating in the runoff vote for the PSD leader, same for $52 \%$ of Kelemen Hunor's supporters. However, these transfers are rather low and their effect even lower if this observation is corroborated with the losses in turnout (previously discussed). This is quite intriguing, since both Corneliu Vadim Tudor and Kelemen Hunor had publicly announced their runoff-support for the social-democrat leader. Still their support was mostly passive, as they avoided getting involved into Mircea Geoană's campaign.

On the incumbent side, Traian Băsescu is remarkably successful in preserving his electorate, with a defection rate of only $3 \%$. As previously highlighted, newcoming voters are his main growth engine between the two rounds (59\% of them vote for him). Traian Băsescu also succeeds in receiving the vote of many supporters of Kelemen Hunor ( $48 \%$ of those voting in the first round for the UDMR candidate), Corneliu Vadim Tudor (42\%), Sorin Oprescu (37\%), and Crin Antonescu (22\%). All these are deviations from the 'theoretical' vote, as Antonescu openly campaigned for Mircea Geoană, Kelemen and Vadim Tudor declared their support for the social-democrat leader, and Oprescu was essentially associated to Social Democrat Party. The next section of this article is dedicated to the cognitive mechanisms behind making second choices among thwarted voters in the presidential elections of 2009. After that, the final section is dedicated to the mobilization and electoral choices of newcomers. These two directions of investigation are crucial for getting a solid explanation on Traian Băsescu's victory in the runoff of the 2009 presidential election.

\section{Thwarted voters in the runoff of the 2009 presidential election}

According to RES panel survey data, the share of thwarted voters within those voting in the first round electorate is of about $27 \%$. In other words, more than a quarter of them still vote in the runoff even in the absence of their preferred candidate. Their share within the electorate is large enough

However, it is hard to believe that such reasoning is that widespread among the electorate to have an impact on the conclusions. 
to presume they had a decisive contribution in setting the result of the runoff, especially in such a close race as the 2009 one. Thwarted voters also represent $26 \%$ of those going to the polls in the runoff.

Let us try to understand the context within which thwarted voters have to make a second choice. First they experience a general state of frustration about the result of the first round, which likely affects their motivation to vote in the runoff. Second, they have to re-assess their alternatives within restricted time boundaries, namely two weeks or less. Third, thwarted voters do not act in a 'new' electoral space; on the contrary they have previous party and ideological options, together with accumulated likes or dislikes of the runoff contenders. Fourth, they usually receive clear runoff-support signals from their preferred candidates. Finally, there are contextual campaign developments between the first and the second round that might affect their vote in the runoff.

If the focus is placed upon the presidential elections of 2009, all the significant candidates not entering the runoff showed their support for Mircea Geoană. However, there were significant variations in how explicit that support was and in the magnitude of involvement in the runoff campaign of the social-democrat leader. A maximum on the scale of involvement was attained by the liberal candidate Crin Antonescu, who actively took part in the electoral campaign of Geoană for the runoff: common political rallies, TV appearances, public messages of support. His failure to enter the runoff also generated the largest share of thwarted voters 'available'. Kelemen Hunor (UDMR) and Corneliu Vadim Tudor (PRM) have chosen to limit their involvement in the runoff to a statement of support for the social-democrat leader. The last relevant candidate, the independent Sorin Oprescu, never issued a runoff-support message. However, his previous long-term PSD membership is expected to have worked in favour of Mircea Geoană.

What are the main campaign developments that might have had an impact on the runoff choices of thwarted voters? A first development is related to the issue and broadcasting of a short film apparently showing president Băsescu hitting a child during an electoral rally in 2004. Issued four days after the first round, the film was obsessively broadcasted by the media prior to the runoff and raised huge debates about its authenticity. A 
second development was the agreement between Crin Antonescu and Mircea Geoană stating their common support for the latter in the presidential runoff and for Klaus Iohannis, the mayor of Sibiu, for prime minister. Consequently, the social-democrat leader had the opportunity to capitalize electorally upon Iohannis' image of excellent administrator, inflated by an extensive series of positive stereotypes related to his German ethnic origin. A third development with likely implications for the runoff choices was Mircea Geoană's failed rally in Timişoara on December 1st, dedicated to signing a 'Partnership for Timişoara'. The event was meant to launch the PSD-PNL collaboration in the city where the 1989 events started from; implicitly it was intended to cleanse the label of successor of the Communist Party from the image of the social-democrat candidate. The political rally failed to reach its aim, due to an anti-PSD counter-rally that ended only after the intervention of the Police. A fourth development is related to a private late-night visit of Mircea Geoană to the house of Sorin Ovidiu Vântu, a powerful business man and media owner, demonized in the speeches of Traian Băsescu for large-scale state capture. Initially published on the website of Academia Cațavencu, a humour weekly magazine, the pictures of the social-democrat leader entering Vântu's house four days before the runoff raised a huge scandal, that outburst during the final television debate, where president Băsescu accused Mircea Geoană of negotiating the state's interest in exchange for campaign support. The final debate occurred three days before the runoff and can be listed as the fifth campaign development that might have reflected on the result of the elections. Prepared in a very tensed context by the two campaign teams, it revealed two candidates prepared to attack each other, but not to exchange ideas. From now on, these five context developments will be referred to as: the incriminating film factor, the Iohannis factor, the Timişoara factor, the Sorin Ovidiu Vântu factor, and the final debate factor. The RES third wave questionnaire includes several items dedicated to these developments (incriminating film, Iohannis factor, televised debate), but unfortunately lacks any references to the Timişoara events and to the Geoană-Vântu meeting. Under these circumstances, the attempt to investigate the effects of context developments on the decision of thwarted voters remains only a partial one. 
How do thwarted voters make their second choices in the runoff of the 2009 presidential elections? In order to answer this central question, an initial focus will be given to identifying differences between the two categories of thwarted voters, the ones turning towards Mircea Geoană and the ones turning towards Traian Băsescu. The next part is dedicated to an effort of developing an explanatory model of vote choice for thwarted voters in the 2009 presidential competition. At this level, the rather limited number of cases available for the analyses $(n=291)$, that suggests prudence with regard to the findings, should be emphasized. However, similar studies on future presidential elections might offer additional clarifications to these initial conclusions.

Regarding socio-demographic characteristics of the voters, the only statistically significant differences between the two categories of thwarted voters are linked to their sector of activity. Thus, employees in the public sector redirect their support in the runoff towards Mircea Geoană far more frequently than towards Traian Băsescu. Similarly, the share of votes for the incumbent within thwarted voters working in the private sector is significantly larger than within overall population. Such a finding does not come as a surprise, as it is totally consistent with the discursive positioning of the two runoff candidates.

The investigation is further focused on the impact of the campaign context developments for the runoff choice among thwarted voters. What are the main findings on this level? First, there are significant differences in terms of calendar of second choice decision-making: thwarted voters choosing Mircea Geoană appear to act according to a logic of 'long-term' decision, as they are more likely to declare having made their second choice before the elections (adjusted standardized residual $=2.4$ ) and not being influenced by the final television debate (ASR=2.2). Conversely, the pro-Băsescu decision appears to be more like a 'short-term' one, likely to have been taken during the campaign after the first round $(\mathrm{ASR}=2.1)$ and under the influence of the televised debate $(A S R=2.1)$. Such a finding is reinforced when the relationship between vote intention for runoff ${ }^{6}$ (formulated with binary alternatives for RES wave 1) and post factum self-declared vote choice (RES

${ }^{6}$ Respondents were asked to express their vote intention in a potential runoff in three alternative scenarios: Geoană vs. Băsescu, Antonescu vs. Băsescu, and Geoană vs. Antonescu. 
wave 3 ) is considered. Thus, for more than $61 \%$ of thwarted voters choosing Mircea Geoană, the vote is consistent with the second-order preference selfdeclared before the elections (RES wave 1), which suggests a dominant longer-term thinking. In the case of pro-Băsescu thwarted voters, the consistency rate is of only $50 \%$.

Second, the two groups of thwarted voters are fundamentally divided on their interpretation of the main campaign developments between the two rounds. The ones voting for Geoană are more likely to consider the Klaus Iohannis support agreement as a good thing $(\mathrm{ASR}=7.6)$ or to believe in the authenticity of the short film showing president Băsescu hitting a child during an electoral rally (ASR=6.7). Conversely, pro-incumbent thwarted voters are more likely to believe the Iohannis agreement as a bad thing $(\mathrm{ASR}=4.8)$ or the incriminating film as a fake (ASR=7.9).

Finally, another finding that might generate further speculations should be emphasized. There are frequent discussions on the local elected officials as vehicles for the mobilization of voters in favour of their parties in the context of national or European elections. Previous empirical analyses suggest such an influence is real (Gheorghiță 2010). However, to the best of our knowledge, the phenomenon has never been investigated in the context of second-order choices of thwarted voters. If the presidential elections of 2009 are to be considered, a statistically significant relation occurs between the mayor's political party and the choice of thwarted voters in the runoff. However, this relation is limited in terms of significance to mayors representing the Social Democrat Party (PSD) and National Liberal Party (PNL). What is really surprising is the direction of the relation: a vote in favour of Mircea Geoană among thwarted voters in the runoff is more likely to happen if the municipality is driven by a PNL mayor ( $A S R=2.4$ ), and significantly less likely to occur if the mayor represents PSD (ASR=-2,6). The relation is exactly reversed if a pro-Băsescu vote is to be considered. In other words, this means that PSD mayors are ineffective in mobilizing the support of thwarted voters for their party's candidate, which contrasts a lot with the case of PNL mayors. Such a finding is hard to explain and any attempt can only be speculative. On the one side, it might be about a demobilization effect among the social-democrat local officials, mainly due to the relative comfort of pre-election opinion polls. On the other side, the same finding can be 
translated in terms of a 'depletion' of electoral growth potential due to the extensive mobilization in the first round.

The main obstacle to the attempt to elaborate an explanatory model of runoff choice for thwarted voters is the limited number of cases available for analysis $(\mathrm{n}=291)$, that might affect the strength of the findings. Having this limitation in mind, the decisions in favour or against alternative explanatory models were guided by two core principles: simplicity and limiting the number of cases lost because of missing data. A logistic regression model was employed, with predictors grouped into two blocks, based on the timing of their impact in the 'funnel of causality', further or closer to the moment of deciding who to vote for. The first block encompasses the relative preference for the candidate and his party as meso-level predictors of secondorder vote choice. By relative preference, we refer to the degree to which the voter prefers one of the two finalists compared to the other one (for a similar logic, see Pierce 2003: 273). The same logic is replicated for their parties. Thus, relative preference for the candidate is calculated as the popularity score $(0-10)$ of the incumbent minus the popularity score of the challenger, thus ranging from -10 to +10 . Positive values indicate a relative preference for the incumbent, negative values a relative preference for the challenger, while the absolute values reflect the intensity of the preference. The relative preference for the party is calculated similarly. The second block encompasses context-related predictors, namely respondents' reactions to campaign developments as the incriminating film factor and the Iohannis factor $^{7}$. The dependent variable is the declared vote in the runoff of the presidential elections, with the vote for the incumbent as reference category. In other words, the logistic regression explains the vote in favour of Traian Băsescu in the runofff. The results are presented in table 4.

What are the main findings? First, the first block (relative preferences for the candidates and parties) has a very large contribution in explaining the runoff

\footnotetext{
7 The first one is measured as opinion on the authenticity of the incriminating film, with dichotomous answer categories. The reference category is the opinion that the film is authentic. The second one is measured as opinion on the statement that the agreement between Mircea Geoană and Crin Antonescu for supporting Klaus Iohannis for prime minister is a good thing for Romania, again with dichotomous answer categories. The reference category is the favourable opinion (yes, it is a good thing).

8 The explanatory model of vote in favour of Mircea Geoană is the 'mirror image' of this model.
} 
choices of thwarted voters. Thus, based on the sympathy scores of finalists and their parties, one could easily predict the choice of $85 \%$ of the thwarted voters. However, it is obvious that things are not as simple as they look. The preferences are measured after the election (RES wave 3), when some of the thwarted voters might have already solved post factum their cognitive dissonances, by adding a plus of rationality to the answers for popularity items. Conversely, short-term campaign developments appear to have a rather small contribution in explaining the decision of thwarted voters. On the other side, they 'strengthen' decisively (and divisively) the choice for or against each of the two finalists. This 'separation effect' looks stronger for the opposition candidate (the theoretical winner of the two campaign developments) than for the incumbent. Yet, overall, long-term established attitudes appear to weigh more on the decision of thwarted voters than recent campaign developments.

Table 4. Explanatory models of runoff vote for Traian Băsescu among thwarted voters

\begin{tabular}{|c|c|c|c|c|}
\hline \multirow{2}{*}{ Predictors } & \multicolumn{2}{|c|}{ Model 1} & \multicolumn{2}{|c|}{ Model 2} \\
\hline & b (SE) & $\exp (b)$ & b (SE) & $\exp (b)$ \\
\hline Relative preference Traian Băsescu vs. Mircea Geoană & $\begin{array}{r}* 0.189 \\
(0.08)\end{array}$ & 1.208 & $\begin{array}{r}+0.167 \\
(0.08)\end{array}$ & 1.182 \\
\hline Relative preference PD-L vs. PSD & $\begin{array}{r}* * *+0.639 \\
(0.12)\end{array}$ & 1.894 & $\begin{array}{r}* * *+0.508 \\
(0.13)\end{array}$ & 1.662 \\
\hline The incriminating film is authentic & - & - & $\begin{array}{r}*-1.145 \\
(0.59)\end{array}$ & 0.318 \\
\hline $\begin{array}{l}\text { The agreement to support Iohannis for prime minister } \\
\text { is a good thing }\end{array}$ & - & - & $\begin{array}{r}*{ }^{*}-1.823 \\
(0.70)\end{array}$ & 0.162 \\
\hline$-2 L L$ & 97.737 & & 87.260 & \\
\hline $\mathrm{R}^{2}$ Cox and Snell & 0.423 & & 0.461 & \\
\hline $\mathrm{R}^{2}$ Nagelkerke & 0.608 & & 0.663 & \\
\hline Cases correctly predicted & $85.0 \%$ & & $87.6 \%$ & \\
\hline
\end{tabular}

Logistic regression, $b$ coefficients with standard errors, $\exp (b)$,

${ }^{* * *} \mathrm{p}<0.001,{ }^{* *} \mathrm{p}<0.010,{ }^{*} \mathrm{p}<0.050,+\mathrm{p}<0.100$

Second, party preference (or rejection) is a better predictor of thwarted voters' runoff choice than candidate preference, although it is about a presidential election. Thus, thwarted voters prefer to rely on the party shortcut than on candidates' evaluation in their attempt to assess the lesser evil in a presidential runoff. This cannot come as a surprise, since the two finalists had already been labelled as 'unattractive' in the context of the first 
round. Moreover, especially in the case of Mircea Geoană, one can easily identify a solid record of sympathies and antipathies targeting his party (PSD) originating in the first years of the post-communist transition. This record, mainly framed in the logic of continuity between the former Communist Party and PSD, has been constantly emphasized in the campaign discourse of Traian Băsescu.

\section{The vote of newcomers in the runoff of the 2009 presidential elections}

As previously noted, newcomers are a little over 9 percent among those voting in the second round of the presidential elections. These are voters that, for various reasons ${ }^{9}$, did not participate in the first round of elections. Newcomers are dominantly mobilized in favour of Traian Băsescu (59.2\%) and it is likely that they contributed to reducing the distance between the incumbent and its social-democrat opponent over domestic polling stations. From this perspective, an analysis of how newcomers are mobilized and how they construct their voting decision is an important piece of the puzzle of voting on December 6, 2009.

How are newcomers different from the other voters? In order to be able to answer this question, newcomers are compared with 'constant' voters, whom participated in both rounds of the elections. Only statistically significant differences are to be discussed here. Obviously, the small number of newcomers $(n=109)$ included in the analysis requires caution in formulating conclusions. There are two main interconnected ways in which newcomers are different from the rest of the voters: they have a significantly lower exposure to political information materialised in (or provoked by) a relative deficit of political trust. What does this mean? First, as compared to the rest of the voters, it is significantly more likely that newcomers did not follow the campaign, be it by watching television (ASR=3.3), listening to radio (ASR=2.2) or discussing with family and friends (ASR=4.1). Connected to this, it is little likely that newcomers accessed daily or almost daily information about the elections during the campaign, no matter the source of information: television (ASR=-5.8), newspapers $(A S R=-3.0)$, radio $(A S R=-$

\footnotetext{
${ }^{9}$ This includes turning 18 between November $23^{\text {rd }}$ and December $6^{\text {th }} 2009$.
} 
2.1), or friends and family (ASR=-3.3). Second, newcomers have definitely lower trust in organisations/institutions than the rest of the voters, especially in mass media ( $\mathrm{t}$ test $=-4.818)$, political parties $(\mathrm{t}=-3.411)$ and the municipal authorities $(\mathrm{t}=-2.430)$. The trust deficit reflects into a form of parochialism, as these voters have no interest in politics and do not feel influenced by politics: they believe election results influence to a little extent the way things are going in the country $(\mathrm{t}=-3.213)$ and their own livelihood $(\mathrm{t}=-1.967)$, thus it is significantly more likely they declare not being interested in politics in general (not at all $\mathrm{ASR}=2.8$, not very interested $\mathrm{ASR}=3.3$ ) or in the presidential campaign (not at all $\mathrm{ASR}=2.4$, not very interested ASR=2.5). Such a picture of newcomers provides enough arguments for an explanation concerning their lack of participation in the first round of the presidential elections, as it illustrates the typical absentee. A question naturally arises: what made these people turn out in the runoff of the December 2009 elections?

A first scenario is that of mobilisation by contagion. In other words, newcomers come from environments where the practice of voting is more common than in the case of absentees (those who did not vote in both rounds). Thus, they feel social pressure towards electoral participation, at least in tensed contexts as a runoff. Asked about the political behaviour of the people in their family or entourage, more than three quarters of the newcomers $(77.1 \%)$ believe half or more of their family members voted, while more than half $(51.4 \%)$ believe all or nearly all of their family members voted. Percentages are visibly higher than in the case of absentees (58.7\% respectively $25.9 \%$ ). When it comes to direct persuasion attempts, approximately $17 \%$ of the newcomers report attempts of people around them to convince them to vote, while only $10 \%$ of the absentees report such attempts. Overall, even though data allows for a limited exploration of this scenario, it is obvious the probability of turning out to vote, even if it is just in the runoff, increases if the individual is surrounded by electorally active people.

A second scenario to explain why some of the newcomers were activated is the contextual mobilisation one, with people responding to certain political developments during the electoral campaign. When asked about the moment they decided whom to vote for, $45 \%$ of the newcomers indicate a 
decision made before the electoral campaign, while the rest indicate a moment during the electoral campaign. $49 \%$ of the newcomers indicate they made a decision after the first round of the elections ${ }^{10}$. It is obvious there is no equal sign between the decision to turn out and the decision to vote with one of the two candidates. Nevertheless, lacking other data, the moment when the voting decision was made is a good enough reference point to identify contextually mobilised newcomers. Thus, it is little likely that those who decided who to vote for before the electoral campaign (from now on referred to as type I newcomers) to have been contextually mobilised. In their case it is more likely that absenteeism in the first round of elections has been an atypical behaviour. Still, if we follow up on the relationship between their declared intention to vote in the case of a potential Băsescu-Geoană and their reported voting behaviour, we notice Traian Băsescu makes relative gains from all categories (Geoană supporters, undecided, blank ballot paper) and records no losses in terms of support. Connected to this, there is an unfavourable trend for the social-democrat leader, as he loses supporters and only marginally wins some undecided voters.

Those who indicate they decided who to vote for between the two rounds of elections are obviously most susceptible to contextual mobilisation (type II newcomers). In this respect, data is available concerning the selfdeclared impact on turnout for three campaign developments: the incriminating film, the Iohannis factor, and the final debate. If their responses are considered, the final debate seems to be the only event which significantly impacted their decision to turn out (more than half of valid responses). The other two events are less frequently mentioned as informing the decision to turn out in the runoff. If we follow up on the relationship between the pre-election self-declared intention to vote in the case of a potential second round Băsescu-Geoană confrontation and the self-reported voting behaviour of type II newcomers we notice the same trend as before: Traian Băsescu is more successful than his opponent in winning votes among the undecided and those decided not to turn out. Moreover, he successfully 'turns over' one in three newcomers whom initially expressed relative preference for Mircea Geoană. Such observations must be regarded

10 This cumulates two categories: during the electoral campaign, after the first round and during the electoral campaign, on election day. 
with caution, given the small $\mathrm{n}$ and the risk of bandwagon effects for such atypical voters as the newcomers. Still, they suggest some form of contextual mobilisation of newcomers existed and worked in favour of the incumbent.

Next, the rationalities of the electoral decision among newcomers are explored. The logic behind these explanatory models is similar to the one previously used in the case of thwarted voters, but the emphasis is on the block of relative preferences for the candidate and the party. The reference categories in the model are the incumbent, Traian Băsescu, and his party, the Democrat-Liberal Party. The explanatory model does not comprise contextual factors, as they are likely to impact mobilisation rather than the decision for who to vote.

Table 5. Explanatory models of runoff vote for Traian Băsescu among newcomers

\begin{tabular}{|c|c|c|c|c|c|c|}
\hline \multirow[t]{2}{*}{ Predictors } & \multicolumn{2}{|c|}{ Model 1} & \multicolumn{2}{|c|}{ Model 2} & \multicolumn{2}{|c|}{ Model 3} \\
\hline & b (SE) & $\exp (b)$ & b (SE) & $\exp (b)$ & b (SE) & $\exp (b)$ \\
\hline Relative preference Traian & $* * *+0.236$ & 1.266 & - & - & +0.061 & 1.063 \\
\hline Băsescu vs. Mircea Geoană & $(0.06)$ & & & & $(0.10)$ & \\
\hline $\begin{array}{l}\text { Relative preference PD-L } \\
\text { vs. PSD }\end{array}$ & 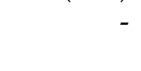 & - & $\begin{array}{r}* * *+1.117 \\
(0.28)\end{array}$ & 3.055 & $\begin{aligned} & * * *+1.161 \\
&(0.33)\end{aligned}$ & 3.194 \\
\hline$-2 \mathrm{LL}$ & 99.996 & & 40.366 & & 36.106 & \\
\hline $\mathrm{R}^{2}$ Cox and Snell & 0.185 & & 0.599 & & 0.603 & \\
\hline R² Nagelkerke $^{2}$ & 0.248 & & 0.803 & & 0.807 & \\
\hline Cases correctly predicted & $69.8 \%$ & & $93.2 \%$ & & $92.5 \%$ & \\
\hline
\end{tabular}

Logistic regression, $b$ coefficients with standard errors, $\exp (b)$, ${ }^{* * *} \mathrm{p}<0.001,{ }^{* *} \mathrm{p}<0.010,{ }^{*} \mathrm{p}<0.050, \dagger \mathrm{p}<0.100$

What are the main findings? Similar to the case of thwarted voters, the relative preferences for candidates and their parties contributes significantly to explaining the newcomers' voting decisions. Based on the relative indicators of sympathy for candidates and their parties, 93\% of the newcomers' voting decisions can be correctly predicted. It must be emphasized that, as indicated by both pseudo- $\mathrm{R}^{2}$, the block of relative preferences is a better predictor in the case of newcomers than it was in the case of thwarted voters. These are hardly surprising observations, as they follow normal theoretical expectations that, in the funnel of causality, newcomers resort to decisionmaking mechanisms closer to the time of the vote.

What is surprising is the huge discrepancy between the explanatory potential of the two categories of relative preferences in the model. Basically, the 
newcomers' decision to vote for one of the two candidates is little explained by the sympathy (or antipathy) for candidates as political actors. The centre of gravity moves towards accepting or rejecting their respective political parties. The same finding was emphasized in the case of thwarted voters, yet here the explanatory potential is much more unbalanced in favour of party sympathy/antipathy. Given this is a group of low mobilized voters with, implicitly, low probability of developing party identification, a scenario suggesting how newcomers vote is dominantly a vote against one of the two parties represented in the runoff (PSD or PD-L) becomes quite credible.

\section{Conclusions}

This article aimed at investigating the main developments within the electorate for the period of time during the two rounds of the 2009 presidential election in Romania that led to the rather unexpected victory of Traian Băsescu. Yet the findings are hard to integrate in a larger picture, and their interpretation is neither as simple, nor as certain as intended. There are many methodological limitations of this attempt that have been highlighted along this article. Nevertheless, such findings can contribute to a better understanding of the mechanisms of electoral decision-making in the context of presidential runoffs.

On a first direction of investigation, focus was given to the vote transfers between the two rounds of the electoral competition. Arguments were offered for the thesis of a highly disciplined PNL electorate, obviously opposed to Traian Băsescu that largely votes for Mircea Geoană in the runoff. On the other side, the incumbent was effective in attracting large segments of thwarted voters, in spite of the generalized runoff-support for socialdemocrat leader offered by candidates eliminated in the first round. Moreover, Traian Băsescu gains the votes of a significant share of newcomers, people that had been absent in the first round.

The second direction of investigation was dedicated to the thwarted voters and their rationalities of making second-order electoral choices in the runoff. In their attempt to choose between the two finalists, thwarted voters appear to rely dominantly on their long-term relative preference for parties and candidates. The party preference is a better predictor of the runoff vote than the 
candidate preference, which is quite natural if we consider that both finalists had already been labelled as politically 'unattractive' by this category of voters in the first round. Campaign developments between the two rounds appear to have a reduced impact for the runoff choice of thwarted voters.

On a third direction of investigation, attention was given to the role of new voters in setting the runoff results across domestic polling stations. The RES panel survey data indicate newcomers being approximately $9 \%$ of the runoff voters. They appear to have a significantly lower exposure to political information and a deficit of political trust. Data do not allow a straightforward answer on why and how were newcomers mobilised to vote in the runoff. However there are empirical evidences in favour of two non-exclusive scenarios: mobilisation by contagion from people in their entourage and contextual mobilisation under the impact of the final debate. The newcomers' vote in the runoff is mainly based on the relative preference for party, namely a rationality by comparison resulting in a preference (or rejection) for one finalist's party over the other's. For most of the newcomers, this is likely to mean a vote against one of the two parties represented in the runoff, the Social Democrat Party (PSD) and the Liberal-Democrat Party (PD-L).

\section{Acknowledgement:}

This work was supported by a grant of the Romanian Ministry of Education, CNCS-UEFISCDI number ID 2174/2008 for the project Romanian Presidential Election Study, 2009 (director Mircea Comşa). The panel study was co-financed by the Soros Foundation Romania, as part of the project Romanian Election Studies (coordinator Ovidiu Voicu).

\section{References:}

Gheorghiță, Andrei. 2010. Cum explicăm votul? Lideri politici, candidați şi constructia deciziei de vot. In Alegerile pentru Parlamentul European România, 2009, eds. Mircea Comşa; Andrei Gheorghiță and Claudiu D. Tufiş, 147-170. Iaşi: Polirom. 
A. Gheorghiță - Vote Transfers, Thwarted Voters and Newcomers in the 2009 Presidential Runoff...

Lazarsfeld, Paul F., Bernard Berelson and Hazel Gaudet. 1968 [1944]. The People's Choice: How the Voter Makes Up His Mind in a Presidential Campaign. New York: Columbia University Press.

Noelle-Neumann, Elisabeth. 1984. The Spiral of Silence: Public Opinion, Our Social Skin. Chicago: University of Chicago Press.

Pierce, Roy. 2003. Modelling electoral second choices: thwarted voters in the United States, France, and Russia. Electoral Studies 22 (2): 265-285. 